\title{
Voltage-gated sodium channel as a target for metastatic risk reduction with re-purposed drugs [version 1; peer review: 2
}

\section{approved]}

\author{
Tomas Koltai (iD
}

Centro de Diagnóstico y Tratamiento de la Obra Social del Personal de la Industria de la Alimentación, Talar, Buenos Aires, C1122AAL, Argentina

\author{
V1 First published: 22 Jul 2015, 4:297 \\ https://doi.org/10.12688/f1000research.6789.1 \\ Latest published: 22 Jul 2015, 4:297 \\ https://doi.org/10.12688/f1000research.6789.1
}

\section{Abstract}

Objective: To determine the exact role of sodium channel proteins in migration, invasion and metastasis and understand the possible antiinvasion and anti-metastatic activity of repurposed drugs with voltage gated sodium channel blocking properties.

Material and methods: A review of the published medical literature was performed searching for pharmaceuticals used in daily practice, with inhibitory activity on voltage gated sodium channels. For every drug found, the literature was reviewed in order to define if it may act against cancer cells as an anti-invasion and anti-metastatic agent and if it was tested with this purpose in the experimental and clinical settings.

Results: The following pharmaceuticals that fulfill the above mentioned effects, were found: phenytoin, carbamazepine, valproate, lamotrigine, ranolazine, resveratrol, ropivacaine, lidocaine, mexiletine, flunarizine, and riluzole. Each of them are independently described and analyzed.

Conclusions: The above mentioned pharmaceuticals have shown antimetastatic and anti-invasion activity and many of them deserve to be tested in well-planned clinical trials as adjunct therapies for solid tumors and as anti-metastatic agents. Antiepileptic drugs like phenytoin, carbamazepine and valproate and the vasodilator flunarizine emerged as particularly useful for anti-metastatic purposes.

\section{Keywords}

Voltage-gated sodium channels, cancer, phenytoin, flunarizine, repurposed drugs, metastasis

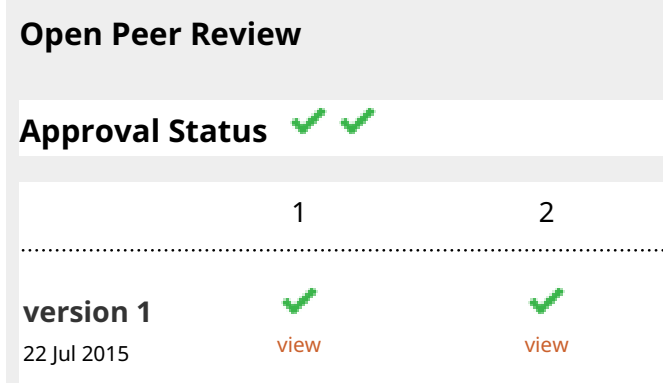

1. Stephen G. Waxman, Yale University, New Haven, USA

2. Michihiro Mutoh, National Cancer Center, Chuo-ku, Japan

Any reports and responses or comments on the article can be found at the end of the article. 
Corresponding author: Tomas Koltai (tkoltai@hotmail.com)

Competing interests: The authors declared no competing interests.

Grant information: The author(s) declared that no grants were involved in supporting this work.

Copyright: $\odot 2015$ Koltai T. This is an open access article distributed under the terms of the Creative Commons Attribution License, which permits unrestricted use, distribution, and reproduction in any medium, provided the original work is properly cited. Data associated with the article are available under the terms of the Creative Commons Zero "No rights reserved" data waiver (CC0 1.0 Public domain dedication).

How to cite this article: Koltai T. Voltage-gated sodium channel as a target for metastatic risk reduction with re-purposed drugs [version 1; peer review: 2 approved] F1000Research 2015, 4:297 https://doi.org/10.12688/f1000research.6789.1

First published: 22 Jul 2015, 4:297 https://doi.org/10.12688/f1000research.6789.1 


\section{Introduction}

The capacity to metastasize is one of the hallmarks of cancer ${ }^{1}$ and usually death due to cancer is not caused by the primary tumor but rather by the metastatic spread ${ }^{2}$. The lack of an effective therapy in prevention of metastasis results in a high mortality rate in oncology. So it seems reasonable that if the risk of metastasis can be reduced, the outlook of cancer patients may significantly improve survival and quality of life. Solving the metastasis problem is solving the cancer problem ${ }^{3}$.

Many natural products, like genistein ${ }^{4}$, resveratrol ${ }^{5}$ and curcumin ${ }^{6,7}$ have shown interesting anti-metastasis activity. The same effect has been observed with older pharmaceuticals like aspirin ${ }^{8}$, not-as-old pharmaceuticals such as celecoxib ${ }^{6,9}$; new pharmaceuticals like ticagrelor ${ }^{10}$, as well as with more sophisticated molecules like dasatinib and ponatinib ${ }^{6}$ or ultrasophisticated drugs, like polymeric plerixafor $^{11}$.

Many other compounds have also been identified as possessing antimetastatic effects, including increases in $\mathrm{NO}^{12}$, cimetidine, doxycycline, heparin and low molecular heparins, and metapristone ${ }^{13}$.

High creativity has been employed in the search for anti-metastatic compounds. For example, Ardiani et al. developed a vaccine-based immunotherapy to enhance CD4 and CD8 T lymphocyte activity against Twist ${ }^{14}$. Twist is a transcription factor involved in invasion and metastasis.

Many known pharmaceuticals that are, or were, in use for other purposes than cancer treatment are demonstrating anti-metastatic activity. This is the case for thiobendazole, which is an antifungal, anti-parasitic drug that has been used in medical practice for over 40 years, but which also shows anti-migratory and apoptosisinducing activity ${ }^{15}$. The introduction of Food and Drug Administration (FDA)-approved products which are used for a purpose different for which it was originally approved is called repurposing of a drug.

Many new drugs are being introduced in the area of anti-metastatic activity. One such example, zoledronic acid ${ }^{16}$ is a biphosphonate that decreases bone metastasis. Denosumab ${ }^{17}$ is another example. It is a monoclonal antibody directed against the receptor activator of nuclear factor kappa B ligand (RANKL) that diminishes the number of circulating cancer cells and prevents bone metastasis. It is in Phase II clinical trials and has the advantage of subcutaneous administration, while zoledronic acid requires intravenous route (for further information on these compounds, see clinical trials NCT01952054, NCT01951586, NCT02129699) ${ }^{18}$.

Metastasis is a multi-step development. The different steps in the metastatic cascade can be targeted with a combination of drugs against each step. Migration and invasion are necessary steps for the metastatic cascade. There is no metastasis without prior migration of malignant cells, so that if migration and invasion are blocked, metastasis should not occur.

Invasion is the first step in metastasis, and in a very simplified view, it can be divided into three stages (Shown schematically in Figure 1):

1. Translocation of cells across extracellular matrix barriers

2. Degradation of matrix proteins by specific proteases

3. Cell migration

\section{Voltage-gated sodium channels}

Neurons and muscle cells (and excitable tissues in general) express voltage-gated sodium channel (VGSC) proteins; tumor cells may also express these proteins. VGSCs are important players in migration and invasion as it will be described in this manuscript.

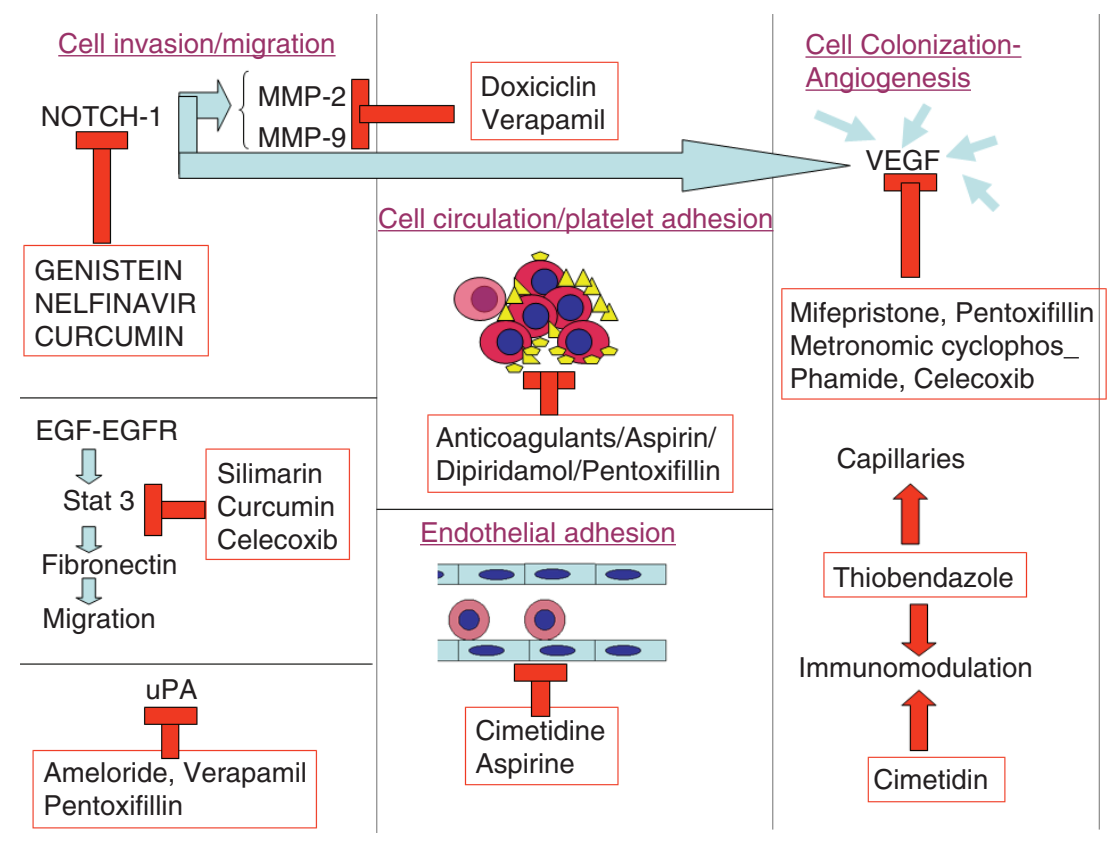

Figure 1. Repurposed drugs acting at different levels of the metastatic cascade. (UPA: urinary plasminogen activator). 
Sodium channels were first described by Hodgkin and Huxley in 1952 and knowledge about structure and physiology of VGSCs are mainly the result of seminal investigations developed by William Catterall ${ }^{19}$.

Sodium channels are glycosylated transmembrane proteins that form passages in the cell membrane for the penetration of sodium into the intracellular space according to their electrical gradients. Voltage-gated sodium channels (also known as VGSCs or ' $\mathrm{NaV}$ ', channels) refers to the mechanism that triggers these proteins to allow sodium movement across the membrane.

There are nine known VGSCs (NaV1.1 to Nav1.9) that are members of the superfamily of VGCSs. NaV1.1, 1.2, 1.3 and 1.6 are found in the central nervous system. NaV1.4 is found in muscle and $\mathrm{NaV} 1.5$ in cardiac muscle ${ }^{20}$.
VGSC is formed by a large subunit $(\alpha)$ and other smaller subunits ( $\beta$ ). The $\alpha$ subunit is the core of the channel and is fully functional by itself, even without the presence of $\beta$ subunits ${ }^{19-21}$.

When a cell expresses VGSC $\alpha$ subunits, this means that it is capable of conducting sodium into the cell. The structure of VGSC can be seen in Figure 2 and Figure 3. VGSCs modulate the exchange of $\mathrm{Na}+$ across the cell membrane and the inflow of this electrolyte spikes the action potential in excitable tissues ${ }^{22}$.

It is well known that expression of VGSCs appears in cancer cells where it is not expressed in their normal counterparts, and plays a significant role in disease progression. Table 1 shows examples of the cancer tissues in which dysregulated expression of VGSCs were identified and the role they play.

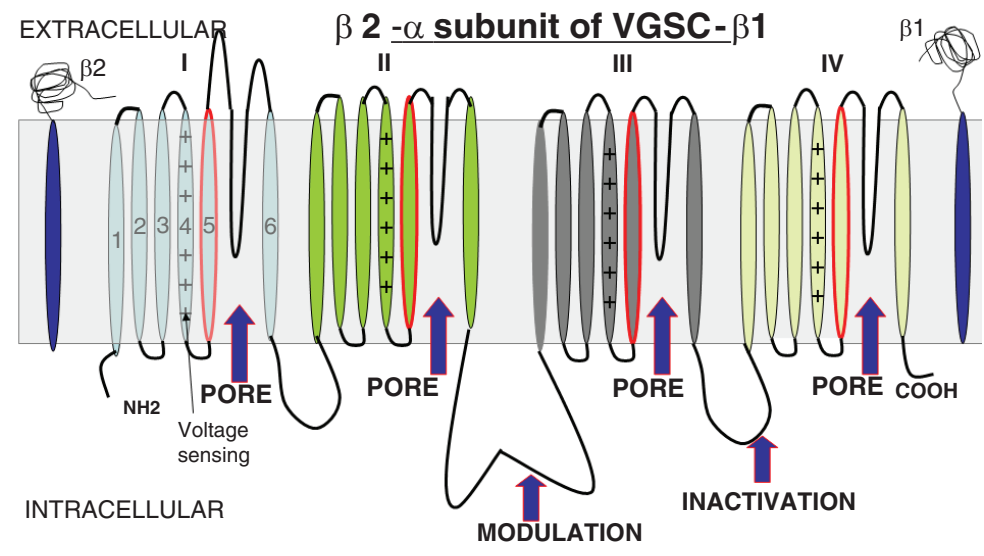

$$
\begin{aligned}
& \text { Voltage-gated channels subunits } \alpha \text { are composed of } 4 \text { repeating pore proteins. } \\
& \text { Each repeat has } 6 \text { coiled sections which spans the cell membrane, a pore gate } \\
& \text { after the 5th crossing, and a positively charged region on the } 4 \text { th crossing which acts } \\
& \text { as a voltage sensor which can open the pore in response to a change in } \\
& \text { eletrical potential. }
\end{aligned}
$$

Figure 2. An idealized drawing of $\alpha$ and $\beta$ units of VGSCs.

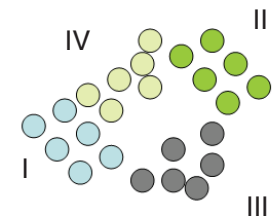

VIEW FROM SURFACE

III

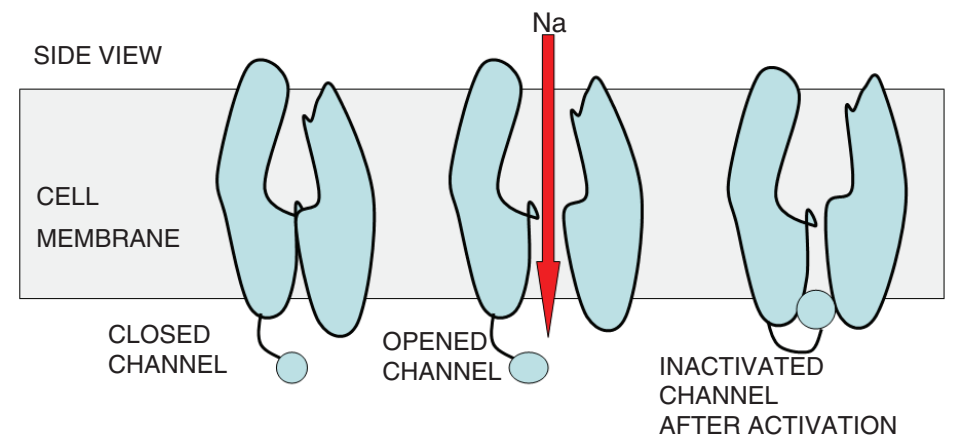

Figure 3. Surface and side view of VGSC. 
Table 1. VGSC functional over-expression in different cancer tissues.

\begin{tabular}{|c|c|c|}
\hline Cancer & Reference & Findings \\
\hline Human breast cancer & Fraser, $2005^{23}$ & $\begin{array}{l}\text { VGSC (neonatal isoform of NaV1.5) was significantly upregulated in metastatic cells. } \\
\text { VGSC activity increased endocytosis, migration and invasion }\end{array}$ \\
\hline $\begin{array}{l}\text { Non small-cell lung } \\
\text { cáncer (NSCLC) }\end{array}$ & Roger, $2007^{24}$ & $\begin{array}{l}\text { Strongly metastatic cell lines have functional VGSCs while normal cells do not have it. } \\
\text { Inhibition of channels with tetrodotoxin (TTX) reduced invasivenes by } 50 \% \text {. }\end{array}$ \\
\hline Cervical cancer cells & Diaz, $2007^{26}$ & $\begin{array}{l}\mathrm{Na}_{v} 1.2, \mathrm{Na}_{v} 1.4, \mathrm{Na}_{v} 1.6 \text {, and } \mathrm{Na}_{v} 1.7 \text { transcripts were detected in cervical cancer cell } \\
\text { specimens. }\end{array}$ \\
\hline Prostate cancer & Bennett, $2004^{27}$ & $\begin{array}{l}\text { VGSC expression increases with invasion capacity that can be blocked with TTX. } \\
\text { Increased VGSC expression is enough to increase invasive phenotype. }\end{array}$ \\
\hline $\begin{array}{l}\text { Metastatic ovarian } \\
\text { cancer cells }\end{array}$ & Gao, $2010^{28}$ & $\begin{array}{l}\text { Highly metastatic ovarian cells showed significantly elevated expression of Nav1.2, } \\
\text { Nav1.4, Nav1.5 and Nav1.7. TTX reduced migration and invasion around } 50 \% \text {. }\end{array}$ \\
\hline $\begin{array}{l}\text { Human colon cancer } \\
\text { cells }\end{array}$ & House, $2010^{29}$ & SCN5A, the gene coding for $\alpha$ sububit of VGSC is a regulator of the invasive phenotype. \\
\hline $\begin{array}{l}\text { T lymphocytes (Jurkat } \\
\text { cells) }\end{array}$ & Fraser, $2004^{30}$ & $\begin{array}{l}\text { Jurkat cells express VGSC and this protein has an important role in invasiveness of these } \\
\text { cells. }\end{array}$ \\
\hline $\begin{array}{l}\text { Pancreatic cancer } \\
\text { cells }\end{array}$ & Sato K, $1994^{31}$ & $\begin{array}{l}\text { MIA-PaCa-2 and CAV cells were tested in vitro and in vivo with phenytoin (PHEN). Both } \\
\text { cell lines showed growth inhibition in a dose dependable manner. This might be due to } \\
\text { VGSC overexpression according to our criteria (the authors think that this was due to } \\
\text { calcium channel blocking). }\end{array}$ \\
\hline $\begin{array}{l}\text { Mesothelial } \\
\text { neoplastic cells }\end{array}$ & Fulgenzi, 2006 32 & $\begin{array}{l}\text { Express VGSCs, particularly NaV1.2, and NaV1.6, and NaV1.7. TTX decreased cell } \\
\text { motility and migration. }\end{array}$ \\
\hline
\end{tabular}

Targeting these channels may represent a legitimate way of reducing or blocking the metastatic process.

The role of sodium channel in invasion, metastasis and carcinogenesis is insufficiently known.

\section{Sodium channel proteins and cancer}

In 1995, Grimes et al. ${ }^{33}$ investigated the differential electrophysiological characteristics of VGSCs in two different rodent prostate cancer cell lines: the Mat-Ly-Lu cell line, which is a highly metastatic line (more than $90 \%$ of metastasis to lung and lymph nodes under experimental conditions) and the AT- 2 cell line with a much lower metastatic potential (less than $10 \%$ chance of developing metastasis in experimental conditions). They found fundamental differences in electrophysiological features between these two cell lines which displayed a direct relationship with in vitro invasiveness. Sodium inward currents were detected only in the Mat-Ly-Lu cell line and inhibition of VGSC protein with Tetrodotoxin (TTX; a powerful inhibitor of VGSCs) significantly reduced the capacity for invasion (mean reduction 33\%). On the other hand, TTX showed no effect on invasion of AT- 2 cell lines. The TTX-induced reduction of invasion showed a direct correlation with the amount of cells expressing VGSC in the culture.
No fundamental differences in the potassium channels were found between the two cell lines, except for a lower density of potassium channels in the Mat-Ly-Lu cell line. The authors concluded that ion channels may be involved in malignant cell behavior and that VGSCs could play a role in the metastatic process.

In 1997, Laniado et al. ${ }^{34}$ investigated the presence of VGSC in human prostate cell lines. As in the Grimes research they used two different cell lines: one with a low metastatic potential: the LN-Cap cell line which is androgen dependent and expresses prostate-specific antigen, and the $\mathrm{PC}-3$ line which is more malignant, does not express prostate-specific antigen and exhibits a high rate of metastatic potential.

As in the work by Grimes et al., they found that PC-3, the more malignant cell line, expressed VGSC protein and that inhibition of this channel protein with TTX reduced invasion in a significant way. LN-Cap cells did not express VGSC.

One of the conclusions reached by the authors was that cancer cells expressing functional VGSC had a selective advantage regarding migration and distant metastasis. In the case of both humans and rodents, not all cells in the highly malignant cell cultures showed 
the presence of the VGSC protein. For example, in PC-3 cell culture only $10 \%$ of cells expressed a functional VGSC protein. This is the reason why the authors consider these cells as a clonal evolution that gives pro-tumor and pro-invasive advantages.

The correlation between VGSC protein expression and invasiveness in human and rat prostate cancer cells was confirmed by Smith et al..$^{35}$ by comparing seven lines of rat prostate carcinoma cells with different metastatic ability, and nine human prostate carcinoma cell lines. In general, invading capacity of the basement membrane and metastatic ability showed a positive correlation with the percentage of cells expressing VGSC. But this positive correlation between percentage of cells expressing VGSCs and the percentage of cells being invasive occurred only up to $27 \%$ of the cells being invasive in the rat series and up to $12 \%$ of cells being invasive in the human series. Authors suggested that these discrepancies may be due to the necessity of other factors for invasive capability besides VGSC presence; i.e. this protein may represent a prerequisite for the invasive phenotype but other requirements must also be achieved for a fullblown invasive phenotype. Fraser et al. ${ }^{36}$ determined the key role played by VGSCs in prostate cancer cells in invasion and motility and showed that TTX and phenytoin (PHEN) that are known VGSC blockers, decreased motility and invasiveness while channel openers increased motility. However, the increased invasion capacity in VGSC-expressing cancer cells is not limited to prostate cancers.
The same features were found in breast cancer cell lines MCF-7 (estrogen receptor positive), MDA-MB-231 and MDA-MB-468 (both estrogen receptor negative).

Baciotglu et al..$^{38}$ when experimenting on a rat model of induced breast cancer showed the importance of inhibiting VGSCs in order to inhibit antioxidant response. They observed a survival improvement in rats treated with a VGSC blocker.

An important location of VGSCs in cancer cells is in a cellular region directly involved in migration and invasion: the invadopodia. Invadopodias are protrusions of the plasma membrane, rich in actin that are strongly related to degradation of the extracellular matrix (ECM). Figure 4 and Figure 5 summarize how invadopodia works and the relation between VGSC and invadopodia.

According to Brisson et al. $.^{39}, \mathrm{NaV} 1.5 \mathrm{Na}+$ channels regulate the NHE-1 exchanger protein that increases proton extrusion with extracellular matrix acidification that promotes invasion and migration through activity of cystein cathepsines and degradation of extracellular matrix ${ }^{40}$.

A second mechanism of invasion promotion was described by Mader et $a .^{41}$ through the EGFR-Scr-cortactin pathway. Src is activated by VGSCs and Src phosphorylates cortactin. Cortactin is

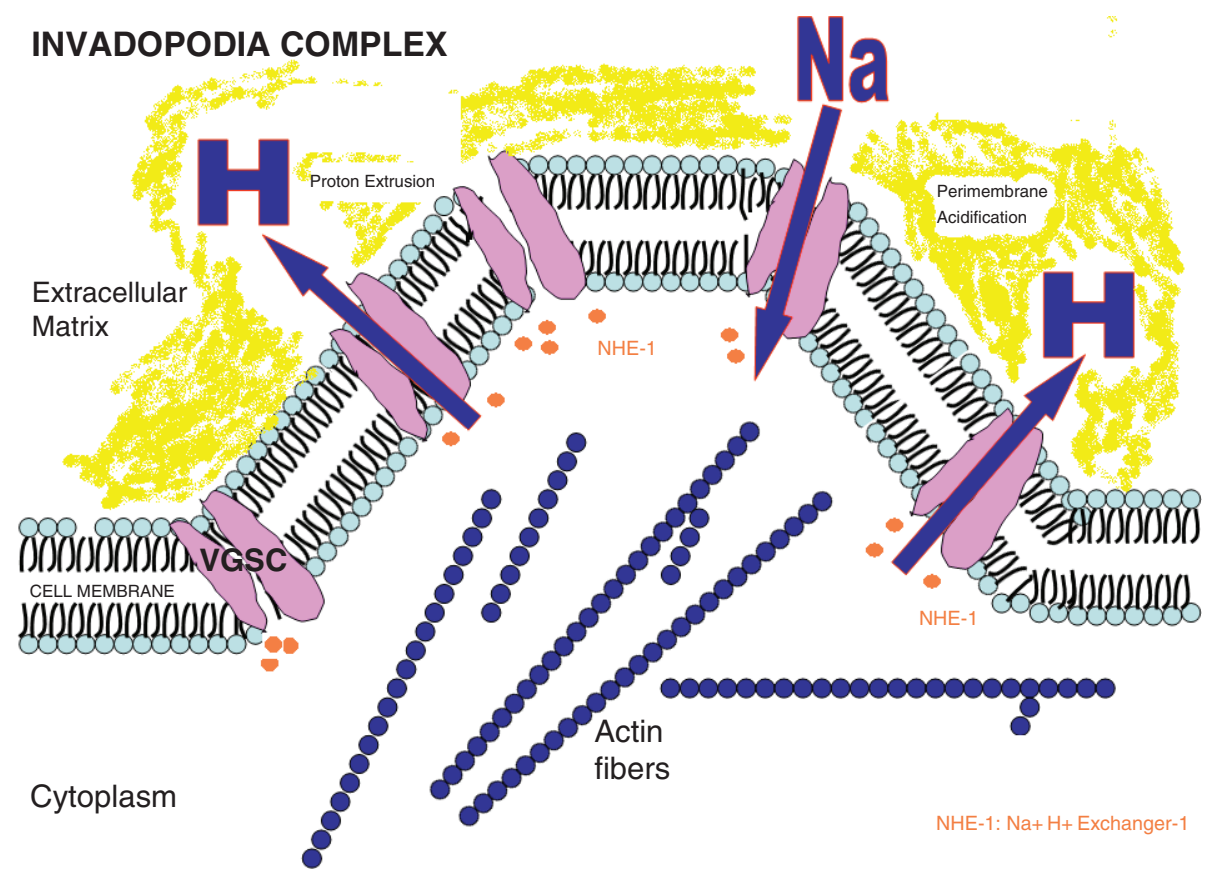

Figure 4. Proton extrusion through VGSC and NHE-1 (sodium hydrogen exchanger-1) produces acidification of extracellular matrix surrounding the cellular membrane (yellow area in the figure). (Brisson 2013 $3^{39}$; Gillet 2009 ${ }^{40}$ ). Acidification activates cathepsine degradation of the extracellular matrix. 


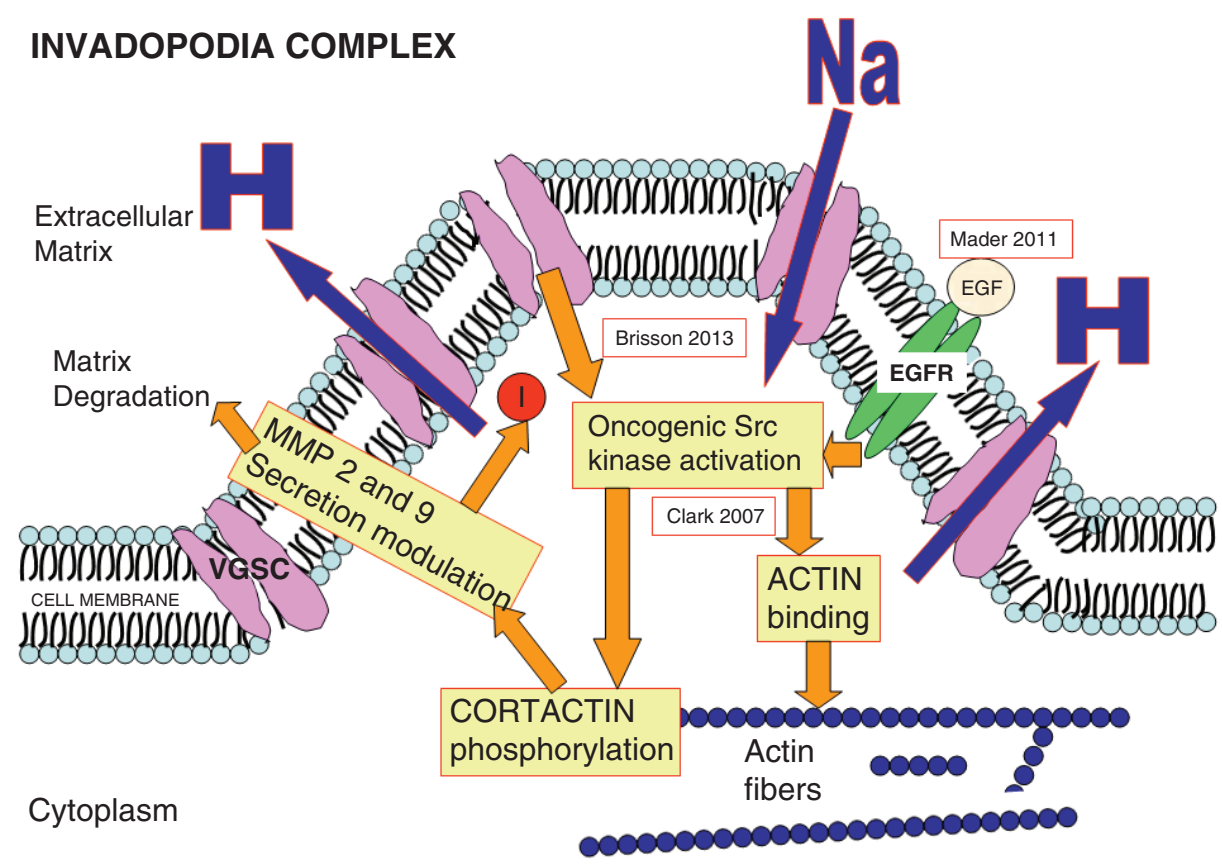

Figure 5. VGSCs. The second mechanism of action is through activation of Src which increases MMP-2 and MMP-9 secretion and activity through phosphorylation of Cortactin. It is postulated that there is a feedback loop starting with MMPs products which induces the development of new invadopodia (Red circle around I). (This figure has been constructed based on references Gillet 2009 ${ }^{40}$, Brisson $2013^{133}$, Clark $2007^{42}$ and Mader $2011^{41}$ ).

involved in MMP-9 and MMP-2 upregulation and secretion as can be seen in Figure 5. These events lead to matrix degradation, an integral step in cancer cell invasion ${ }^{42}$.

There are nine different VGSC $\alpha$ subunits and four different $\beta$ subunits. The expression of these subunits may vary in the different tumor cells ${ }^{21}$. For example, NaV 1.5 is overexpressed in astrocytoma, breast and colon cancer. $\mathrm{NaV} 1.7$ is found in breast, prostate and non small-cell lung cancer (NSCLC) and NaV 1.6 in cervical and prostate cancer. This suggests that the $\alpha$ subunits seem to be tissue specific.

The main players in the invadopodia complex, besides the VGSCs are Src kinase, cortactin and Rho-A GTPase. The exact relation between these players is not fully known and needs further research. (For further reading on invadopodia and cortactin, see references $43,44)$.

One possible relation between invadopodia-Src-VGSCs is described in Figure 6.

Onganer and Djamgoz ${ }^{45}$ proposed the hypothesis that VGSC upregulation enhances the metastatic phenotype by enhancing endocytic membrane activity in SCLC.

Andrikopoulus et $a l .{ }^{50}$ have demonstrated that VGSCs have pro-angiogenic functions by significantly increasing vascular endothelial growth factor (VEGF) signaling in endothelial cells. Endothelial cells express NaV1.5 and NaV1.7. TTX blocks, and NaV1.5 RNAi decreases endothelial cell proliferation and tubular differentiation that are essential steps in the angiogenesis process.

The important implications of VGSCs in cancer progression and invasion led Litan and Langhans ${ }^{51}$ to express that cancer is a channelopathy (For further reading on structure and functions of VGSC see reference 52).

\section{Material and methods}

A search was performed in the medical literature to find pharmaceuticals already in use for other purposes than cancer, that as an off-target effect could inhibit VSGCs and to determine if these pharmaceuticals can actually decrease migration, invasion and metastatic potential of cancer. A Pubmed advanced search retrieved 50519 articles under the search condition "voltage-gated sodium channel blocker" during the period of 1981-2015.

The articles that considered drugs that were not in clinical use or FDA-approved were not included in this study, with the exception of resveratrol and natural polyphenols.

The following drugs fulfilling these criteria were found: phenytoin, carbamazepine, lamotrigine valproate, ranolazine, resveratrol, ropivacaine, lidocaine, mexiletine, flunarizine, and riluzole. 


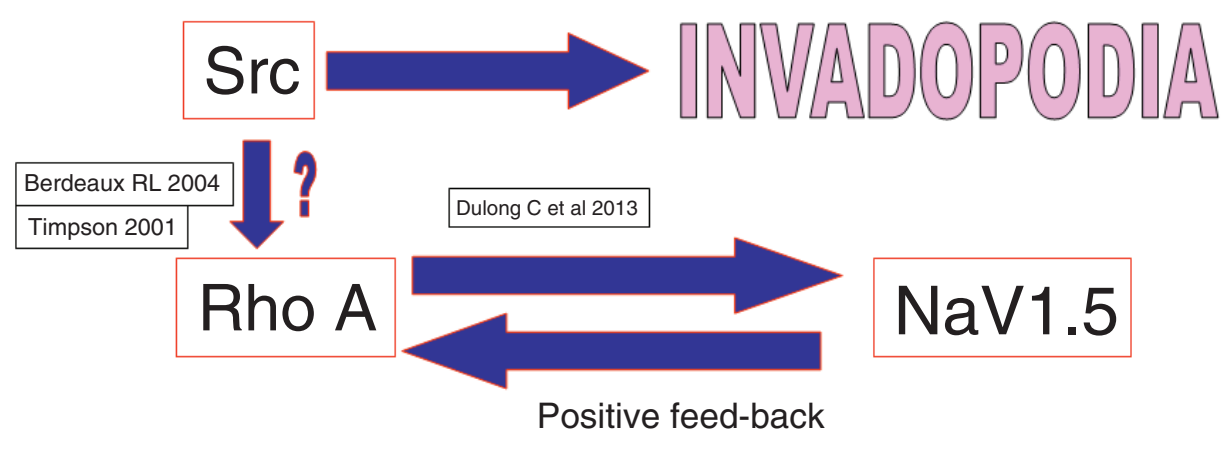

Figure 6. Tarone et al. ${ }^{46}$ in 1985 reported the relation between the oncogenic Src and promotion of invadopodia. Berdeaux et al. ${ }^{47}$ reported that the small molecule GTPase Rho A activity is under control of oncogenic Src and localizes in the invadopodia complex and Durlong et al. ${ }^{48}$ (2013) showed that Rho-A regulates the expression and activity of NaV1.5 and found a positive feedback between NaV1.5 and Rho A in breast cancer cells. According to Timpson et al. ${ }^{49}$, cooperation between mutant p53 and oncogenic Ras activates Rho-A.

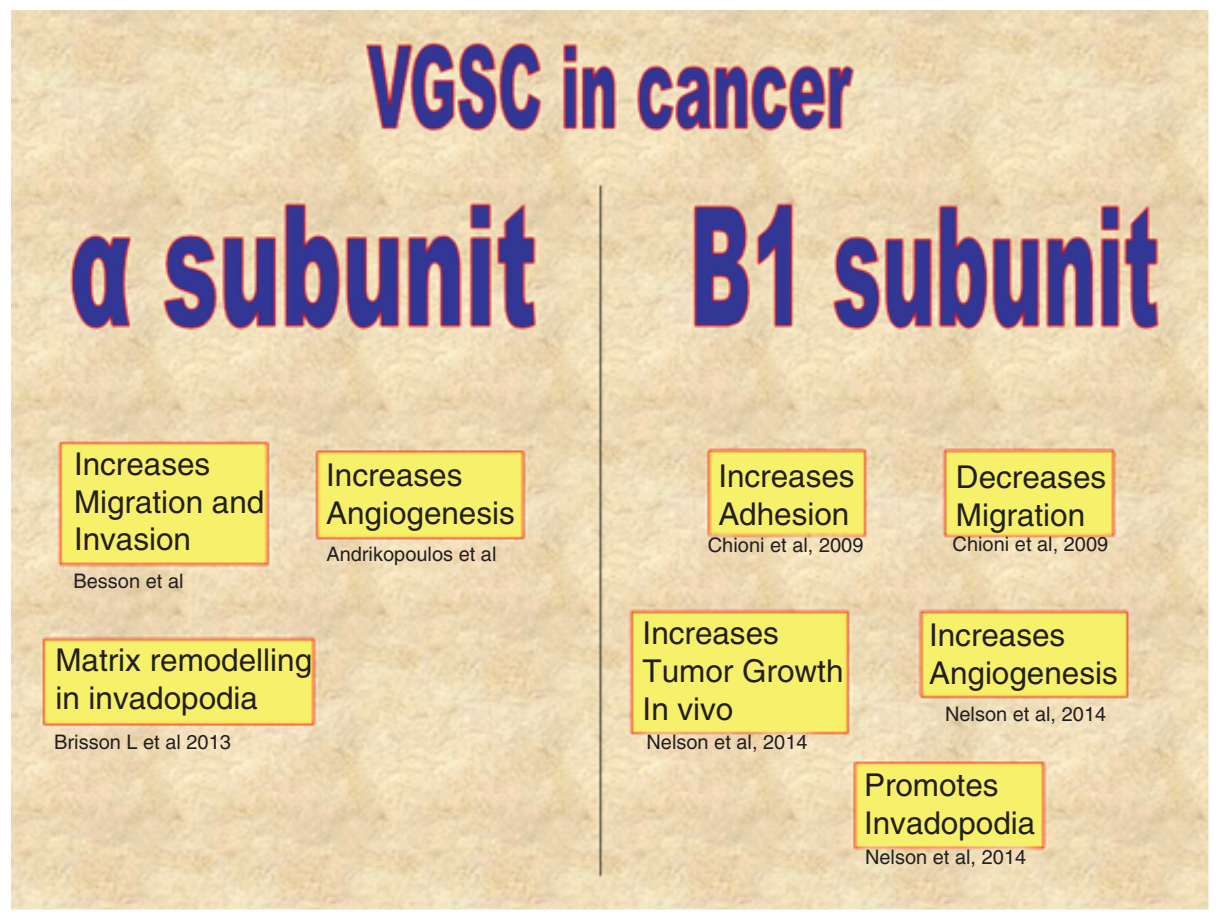

Figure 7. Activities of alpha and beta-1 subunits of VGSCs in cancer ${ }^{131-133}$.

A new search was performed in Pubmed for each of the above listed pharmaceuticals with two search criteria: 1) the drug and 2) the term cancer. The period considered was from 1962 to the current time.

Those VGSC blocking drugs that exhibited anti-cancer activity based mainly by other mechanisms are only briefly mentioned; valproic acid and lamotrigine probably act against cancer by histone deacetylase inhibition and riluzole's anti-cancer mechanism is probably related to the glutamatergic pathway.
Tetrodotoxin is also analyzed in spite of the fact that it is not in clinical use, because it is the traditional model molecule of VGSC blocking, against which other drugs are comparatively tested in the experimental setting.

\section{Results}

Tetrodotoxin (TTX)

Many biological toxins like those found in scorpions and sea anemones develop their toxicity by introducing modifications to the 
properties of VGSCs ${ }^{52}$. This toxicity can be achieved by inactivation of VGSCs (as in the case of TTX) or on the contrary by persistent activation of the channel (in the case of veratridine, acinitine and many others).

TTX is a powerful biological neurotoxin found in fishes of the Tetraodontiformes order and certain symbiotic bacteria. TTX binds to VGSCs and blocks its activity, mainly in the nervous system. It is used as a biotoxin for defensive or predatory purposes. TTX binds to the extracellular portion of VGSC, disabling the function of the ion channel and results in a very poisonous effect producing death through respiratory paralysis ${ }^{22}$.

Due to its high toxicity it is not used as a therapeutic agent, but TTX has been very useful in the experimental setting for the study of VGSCs physiology.

\section{Phenytoin (Diphenylhydantoin; PHEN)}

PHEN is an anticonvulsant that has been identified as a sodium channel blocker ${ }^{53,54}$ which has been held responsible for inducing lymphoma, pseudolymphoma, hematological malignancies and other cancers in patients under chronic treatment ${ }^{55}$. This carcinogenic effect of phenytoin was not confirmed in large epidemiological studies ${ }^{56}$. PHEN diminishes cell mediated immunity ${ }^{57}$.

Vernillo et al. in $1990^{58}$ found that phenytoin inhibited bone resorption in rat osteosarcoma cells through significant reduction of collagenase and gelatinase activities. But Dyce et al..$^{59}$ did not find evidence of PHEN's gelatinase inhibitory activity in B16 melanoma cells in vitro. This may be evidence of tissue-specific activity which has not been investigated any further. Dyce et al. did not find important anti-metastatic activity either in a melanoma tail injection model in mice. But when the data of this publication is examined in detail, it seems that the anti-metastatic activity is not so low as mentioned by the authors: they found that after injection of tumor cells in the mice protected with PHEN, the animal developed mean pulmonary colonies $4.6+/-3.1$ but when the mice received no PHEN, developed. $10.2+/-9.9$ colonies. Beyond any statistical analysis the difference seems important.

Yang et al. ${ }^{60}$ found that NaV 1.5 was over-expressed in breast cancer cells with high metastatic potential, and the anticonvulsivant PHEN had the ability to reduce migration and invasion at clinically achievable concentrations in MDA-MB-231 cells (which are strongly metastatic) and showed no effects on MCF-7 cells with low metastatic potential.

PHEN blocks $\mathrm{Na}^{+}$channels and has a high affinity for VGSCs in the inactivated state of the channel ${ }^{61}$. Compared with verapamil, lidocaine and carbamacepine, PHEN had an intermediate potency between verapamil and lidocaine, being verapamil the strongest inhibitor and carbamazepine the weakest.

Abdul et al. ${ }^{62}$ studied the effect of four anticonvulsants (PHEN, carbamazepine, valproate and ethosuxinide) on the secretion of prostate specific antigen and interleukin-6 in different human prostate cancer cell lines. PHEN and carbamazepine inhibited the secretion of both.

Fadiel et al. ${ }^{63}$ found that PHEN is a strong estrogen receptor $\alpha$ antagonist at clinically achievable concentrations and at the same time is a weak agonist.

Table 2. Summary of PHEN's activity against cancer and metastasis.

\begin{tabular}{|c|c|}
\hline Reference & Findings \\
\hline Nelson, $2015^{64}$ & $\begin{array}{l}\text { PHEN at clinically achievable concentration reduces breast cancer growth, invasion and metastasis in vivo in } \\
\text { a xenograft model. }\end{array}$ \\
\hline Yang M, $2012^{60}$ & $\begin{array}{l}\text { At clinically achievable concentration PHEN inhibited migration and invasion of highly metastatic breast } \\
\text { cancer MDA-MB-231 cell line, and had no effect on MCF- } 7 \text { cell line which has a low metastatic potential and } \\
\text { do not express VGSCs. }\end{array}$ \\
\hline Lee Ts, $2010^{65}$ & DPTH-N10 a phenytoin derivate drug, inhibits proliferation of COLO 205 colon cancer cell line. \\
\hline Lyu Y, $2008^{66}$ & $\begin{array}{l}\text { DPTH-N10 a phenytoin derivate drug, shows strong anti-angiogenic activity. Inhibits HUVEC proliferation and } \\
\text { capillary like tube formation. }\end{array}$ \\
\hline Sikes, $2003^{67}$ & New VGSC blockers based on PHEN, showed increased inhibition of prostate cancer growth. \\
\hline Anderson, $2003^{68}$ & $\begin{array}{l}\text { Developed new VGSC blockers based on the PHEN binding site study. These new VGSC blockers showed } \\
\text { potent inhibition of prostate cancer cells growth (Androgen independent PC3 line). }\end{array}$ \\
\hline Fraser, $2003^{36}$ & PHEN decreased motility of prostate cancer cells. \\
\hline Abdul, $2001^{62}$ & PHEN and carbamazepine decreased PSA secretion in human prostate carcinoma cell lines. \\
\hline Lobert, $1999^{69}$ & PHEN has inhibitory effects on microtubule assembly and has additive effects with vinblastine. \\
\hline Kawamura, $1996^{70}$ & PHEN potentiates vinblastine citotoxicity. \\
\hline Sato K, $1994^{31}$ & PHEN decreased growth of MIA PaCa-2 (pancreatic cancer cells). \\
\hline Lang DG, $1993^{71}$ & $\begin{array}{l}\text { PHEN, Carbamazepine and lamotrigine are inhibitors of sodium channels and reduces glutamate release in } \\
\text { rat neuroblastoma cells. }\end{array}$ \\
\hline Tittle, $1992^{72}$ & PHEN decreased growth in six murine tumor cell lines of lymphoid origin. \\
\hline
\end{tabular}


There is an undesired side effect of PHEN that may represent a drawback for its use in cancer: immunological depression ${ }^{73-76}$. This is an issue that deserves further research. Finally it has to be mentioned that PHEN interacts with many other pharmaceuticals, particularly those usually employed in chemotherapy.

In summary, the main activities developed by PHEN in relation with cancer are:

VGSC blocking, microtubule polymerization blocking, immunosuppression, calcium channel blocking and enhancement of vinblastine cytotoxicity.

\section{Carbamazepine}

Carbamazepine is a sodium channel blocker, pro-autophagy agent and histone deacetylase inhibitor that has been in use since 1962 for the treatment of seizures, neuropathic pain and bipolar disorders and has shown interesting anti-metastatic potential in the experimental setting ${ }^{77}$. Studies have also insinuated preventative effects in prostate cancer ${ }^{78}$.

Carbamazepine induces Her2 protein degradation through the proteosome without modifying its production ${ }^{79}$. This activity seems to be related to histone deacetylase inhibition rather than VGSC blocking. Growth inhibition in estrogen-receptor positive breast cancer cell lines seems probably a histone deacetylase inhibitor effect ${ }^{80}$.

Oxcarbazepine, a molecule related to carbamazepine is also a sodium channel blocker ${ }^{81}$ and a potassium channel blocker, but it has not been investigated for cancer.

The anti-cancer mechanisms shown by carbamazepine are in summary:

1) VGSC blocker as anti-metastatic ${ }^{77}$.

2) Histone deacetylase inhibition ${ }^{82}$.

3) Her2 degradation by proteasome ${ }^{79}$.

Valproic acid (VAL)

An anticonvulsivant drug that exerts multiple actions related to anticancer effects: calcium channel blocker, VGSC blocker, inhibition of histone deacetylase, potentiation of inhibitory activity of GABA, decreases angiogenesis, interferes with MAP kinase pathways and the $\beta$ catenin-Wnt pathway ${ }^{83}$. Val is being tested in various clinical trials in leukemias and solid tumors ${ }^{84}$. Most of the anti-tumor activities of VAL seem to be related to the inhibition of histone deacetylase rather than VGSC blocking and further discussion goes beyond the scope of this review.

\section{Ranolazine}

Ranolazine, (Ranexa) is an antiarrhythmic drug indicated for the treatment of chronic angina that was first approved by FDA in 2006. Common side effects are dizziness, constipation, headache and nausea ${ }^{85}$.
Ranolazine inhibits the late inward sodium current in heart muscle, so that it works as a sodium channel inhibitor. Ranolazine is metabolized by the CYP3A enzyme.

Driffort et al. ${ }^{86}$ demonstrated that ranolazine inhibition of NaV1.5 reduced breast cancer cells invasiveness in vivo and in vitro using the highly invasive MDA-MB-231 breast cancer cell line. This drug also efficiently decreased the activity of the embryonic/neonatal isoform of NaV1.5 (the active isoform usually found in human breast cancer cells). Ranolazine did not change the viability of the cell. It also decreased the pro-invasive morphology of MDA-MB-231 breast cancer cells. They also demonstrated that injection of cancer cells through the tail vein of nude mice at non-toxic doses achieved a significant reduction in metastatic colonization.

\section{Resveratrol and other polyphenols}

Certain biologically active natural phenols like resveratrol and genistein have shown effects on VGSCs, increasing hyperpolarized potentials during steady state inactivation ${ }^{88}$.

Resveratrol's inhibitory effects on VGSC has consequences for the behaviour of metastatic cells. Fraser et al ${ }^{89}$ showed that resveratrol significantly decreased lateral and transversal motility and invasion capacity of rat prostate cancer cells (MAT-Ly-Lu cells), without changes in cellular viability. They also found that resveratrol inhibited VGSC in a dose-dependent manner and using TTX with resveratrol did not increase VGSC inhibition nor metastatic cell behavior. Resveratrol also inhibits epithelial sodium channels ${ }^{90}$.

Resveratrol is not the only polyphenol with VGSC blocking activity: quercetin and catechin showed similar effects ${ }^{91}$ in ventricular myocytes and genistein in rat cervical ganglia ${ }^{92}$ and nociceptive neurons ${ }^{93}$.

\section{Gabapentin}

Gabapentin is used for the treatment of pain and decreases expression of NaV1.7 and ERK-1/ERK-2 in ganglion neurons ${ }^{94,95}$ and expression of $\mathrm{NaV} 1.2^{96}$. We found no publications about gabapentin as a possible anti-metastasis or anti-invasion treatment.

\section{Riluzole}

Riluzole is a drug used for amyotrophic lateral sclerosis and it is a known sodium channel blocker. This effect was demonstrated in human prostate cancer cell lines ${ }^{97}$. Most likely, the anticancer activity of riluzole is mainly related to other anticancer characteristics of this drug like downregulation of the glutamatergic pathway ${ }^{98}$.

\section{Flunarizine}

Flunarizine is a calcium channel blocker with a long plasma halflife, used in migraine prevention, vertigo and adjuvant treatment of epilepsy, but has shown important activity as a VGSC blocker ${ }^{99-101}$. It binds calmodulin.

At low temperatures (22 degrees) flunarizine potentiate the binding of phenytoin to $\mathrm{VGSC}^{102}$. 
Flunarizine has shown anti-cancer activities in lymphoma and multiple myeloma ${ }^{103}$, and leukaemia ${ }^{104}$, but these anti-cancer activities were apparently related to induction of apoptosis, which is not a consequence of VGSC blockage. On melanoma cells, flunarizine showed decreased motility and invasion in vitro ${ }^{105,106}$. Flunarizine inhibited migration and phagocytosis in B16 melanoma cells and M5076 macrophage-like cancer cells ${ }^{107}$.

According to data found in medical literature we may consider anticancer activities of flunarizine in the following way:

a) Activities dependent on VGSC blocking: decreased motility and invasion ${ }^{105-107}$.

b) Activities dependent on calcium channel blocking: vasodilatation and increased concentration of chemotherapeutic drugs in tumor tissues ${ }^{108-110}$, and increased radiosensitivity due to better oxygen delivery to anoxic areas of the tumor $^{111}$.

c) WNT inhibition ${ }^{103}$.

d) Inhibition of lymphangiogenesis ${ }^{112}$.

e) Increase of melphalan`s citotoxicity in resistant ovarian cancer cells ${ }^{113}$ and in rhabdomyosarcoma ${ }^{114}$.

f) Positive modulation of doxorubicin in multidrug resistant phenotype colon adenocarcinoma cells ${ }^{115}$.

g) Decreased blood viscosity improving oxygen delivery to the tumor $^{116}$.

h) Other anti-tumor activities: apoptosis and growth rate inhibition $^{103,104,117}$.

Flunarizine has not been tested in cancer trials. The fact that it can significantly reduce motility in melanoma cells which is a highly metastasizing tumor and is also an inhibitor of lymphangiogenesis, makes it an interesting adjuvant therapy that deserves further research. The possible synergy with phenytoin is also an issue that should be explored.

However, flunarizine has also shown cytoprotective effects in certain tissues (auditory cells) against cisplatin ${ }^{118}$ and flunarizine may induce Nrf-2 overexpression that confers resistance to chemotherapy in some tumors like Her2 positive breast cancer ${ }^{119}$.

\section{Local anaesthetics}

Local anaesthetics eliminate pain through VGSC blocking on nociceptive neurones.

Local anaesthetics like lidocaine have shown interesting anti-cancer effects in various cancer cells. Lidocaine is a VGSC blocker. The mechanisms involved in decreased proliferation seems related to the inhibitory actions of local anaesthetics on EGFR ${ }^{120}$ rather than VGSC blocking. Inhibition of invasion found in cancer cells treated with lidocaine (HT1080, HOS, and RPMI-7951) by Mammoto et al. was attributed by the authors to shedding of the extracellular domain of heparin binding epidermal growth factor-like growth factor and not to VGSC blocking ${ }^{121}$.

Baptista-Hon et al. described a decrease in metastatic potential of colon cancer cells (SW620 cells) by ropivacaine and decrease of Nav1.5 function (adult and neonatal isoforms) $)^{122}$.

Piegeler et al., 2012 identified decreased Src activity produced by amide-linked anaesthetics as an independent mechanism of migration and invasion decrease ${ }^{123}$.

\section{Other drugs}

Other drugs that have shown significant VGSC blocking activity and may have activity in the fight against migration, invasion and metastasis are: fluoxetin blocks NaV1.5 ${ }^{124}$, and mexiletine ${ }^{125}$.

Intravenous propofol has been recognized as an anti-invasion drug in HeLa, HT1080, HOS and RPMI-75 cells by decreasing actin stress-fiber formation and focal adhesion inhibition, but this drug is not a VGSC blocker and the probable mechanism is through Rho-A modulation $^{126}$.

All of the drugs we have mentioned are low cost pharmaceuticals, have predictable and well known side effects, and therefore they are adequate candidates for further clinical trials.

\section{Discussion}

Functionally active VGSCs are expressed in many metastatic cancer cells. This functional expression is an integral element of the metastatic process in many different solid tumors.

The essential role of this protein in invadopodia has been established, so VGSCs became a legitimate target to decrease migration, invasion and metastasis. Repurposed drugs like anticonvulsants, (phenytoin in particular) have shown interesting anti-invasion effects.

Carbamazepine's ability to induce Her2 protein degradation should be considered an interesting association to trastuzumab.

Targeting VGSCs may act in synergy with anti-angiogenic treatments and with other chemotherapeutic drugs like vinblastine.

On the other hand in the review by Besson et al. ${ }^{127}$ there is a very important remark: VGSC is also present in macrophages and cells related with the immunologic system, so that disrupting VGSC's activity may deteriorate also anti-tumor immunologic mechanisms.

Flunarizine represents a particularly interesting molecule because it may attack cancer from four different angles: invasion and migration through VGSC blocking, WNT pathway down-regulation, decreased lymphangiogenesis and better oxygenation of hypoxic areas which permits a better arrival of chemotherapeutic drugs and increased sensitivity to radiation. It has never been tested in clinical trials for cancer treatment. 


\section{Future directions}

New VGSCs blockers are under research. Sikes et al. ${ }^{67}$ developed new blockers based on the phenytoin binding site to VGSC. They found compounds with enhanced activity in VGSC blocking and antitumor activity against human prostate cancer cells.

The association of two or more VGSC blockers may show synergistic enhanced anti-metastatic activity. Nerve growth factor (NGF) increases the number of VGSCs ${ }^{129}$; tanezumab, a new NGF inhibitor diminishes the amount of VGSCs ${ }^{128}$, so we may assume that tanezumab may develop synergistic activity with VGSC blockers. Tanezumab has not been tested in cancer and we think it deserves more research because NGF is also an anti-apoptotic protein ${ }^{130}$.

Stettner et al. ${ }^{134}$ found that men over 50 years of age may be benefited with the use of anticonvulsivants, regarding prostate cancer prevention because they observed lower PSA levels compared with control groups. They also described a ranking of this preventive activity: valproic acid>levetiracetam $>$ carbamazepine/oxcarbazepine $>$ lamotr igine. The authors also observed synergy between these drugs.

\section{Conclusions}

Repurposed VGSC blocker drugs, particularly phenytoin, flunarizine and polyphenols, deserve clinical trials as complementary treatment to decrease the metastatic risk.

\section{Competing interests}

The authors declared no competing interests.

Grant information

The author(s) declared that no funds were involved in supporting this work.
1. Hanahan D, Weinberg RA: Hallmarks of cancer: the next generation. Cell. 2011; 144(5): 646-74.

PubMed Abstract | Publisher Full Text

2. Mehlen P, Puisieux A: Metastasis: a question of life or death. Nat Rev Cancer 2006; 6(6): 449-458.

PubMed Abstract | Publisher Full Text

3. Taketo MM: Reflections on the spread of metastasis to cancer prevention. Cancer Prev Res (Phila). 2011; 4(3): 324-328.

PubMed Abstract | Publisher Full Text

4. Pavese JM, Krishna SN, Bergan RC: Genistein inhibits human prostate cancer cell detachment, invasion, and metastasis. Am J Clin Nutr. 2014; 100(Suppl 1): 431S-436S.

PubMed Abstract | Publisher Full Text | Free Full Text

5. Yang X, Li X, Ren J: From French Paradox to cancer treatment: anti-cance activities and mechanisms of resveratrol. Anticancer Agents Med Chem. 2014; 14(6): 806-25.

PubMed Abstract | Publisher Full Text

6. Xiong A, Yang Z, Shen Y, et al.: Transcription Factor STAT3 as a Novel Molecular Target for Cancer Prevention. Cancers (Basel). 2014; 6(2): 926-57. PubMed Abstract | Publisher Full Text | Free Full Text

7. Kronski $\mathrm{E}$, Fiori $\mathrm{ME}$, Barbieri $\mathrm{O}$, et al: $\mathrm{miR} 181 \mathrm{~b}$ is induced by the chemopreventive polyphenol curcumin and inhibits breast cancer metastasis via down-regulation of the inflammatory cytokines CXCL1 and -2. Mol Oncol. 2014; 8(3): 581-95

PubMed Abstract | Publisher Full Text

8. Langley RE, Rothwell PM: Aspirin in gastrointestinal oncology: new data on an old friend. Curr Opin Oncol. 2014; 26(4): 441-7.

PubMed Abstract | Publisher Full Text

9. Li WW, Long GX, Liu DB, et al:: Cyclooxygenase-2 inhibitor celecoxib suppresses invasion and migration of nasopharyngeal carcinoma cell lines through a decrease in matrix metalloproteinase-2 and -9 activity. Pharmazie. 2014; 69(2): 132-7.

PubMed Abstract | Publisher Full Text

10. Gebremeskel S, LeVatte T, Liwski RS, et al: The reversible P2Y12 inhibitor ticagrelor inhibits metastasis and improves survival in mouse models of cancer. Int J Cancer. 2015; 136(1): 234-40.

PubMed Abstract | Publisher Full Text

11. Li J, Oupický D: Effect of biodegradability on CXCR4 antagonism, transfection efficacy and antimetastatic activity of polymeric Plerixafor. Biomaterials. 2014; 35(21): 5572-9.

PubMed Abstract | Publisher Full Text | Free Full Text

12. Lu Y, Yu T, Liang H, et al:: Nitric oxide inhibits hetero-adhesion of cancer cells to endothelial cells: restraining circulating tumor cells from initiating metastatic cascade. Sci Rep. 2014; 4: 4344 .

PubMed Abstract | Publisher Full Text | Free Full Text

13. Wang J, Chen J, Wan L, et al.: Synthesis, spectral characterization, and in vitro cellular activities of metapristone, a potential cancer metastatic chemopreventive agent derived from mifepristone (RU486). AAPS J. 2014; 16(2): 289-98.

PubMed Abstract | Publisher Full Text | Free Full Text

14. Ardiani A, Gameiro SR, Palena C, et al:: Vaccine-mediated immunotherapy directed against a transcription factor driving the metastatic process. Cancer Res. 2014; 74(7): 1945-57.

PubMed Abstract | Publisher Full Text

15. Zhang J, Zhao C, Gao Y, et al:: Thiabendazole, a well-known antifungal drug, exhibits anti-metastatic melanoma B16F10 activity via inhibiting VEGF expression and inducing apoptosis. Pharmazie. 2013; 68(12): 962-8. PubMed Abstract

16. Rietkötter E, Menck K, Bleckmann A, et al:: Zoledronic acid inhibits macrophage/ microglia-assisted breast cancer cell invasion. Oncotarget. 2013; 4(9): 1449-60. PubMed Abstract | Free Full Text

17. Rolfo C, Raez LE, Russo A, et al:: Molecular target therapy for bone metastasis: starting a new era with denosumab, a RANKL inhibitor. Expert Opin Biol Ther. 2014; 14(1): 15-26.

PubMed Abstract | Publisher Full Text

18. NCT01952054, NCT01951586, NCT02129699 Reference Source

19. Catterall WA: Voltage-gated sodium channels at 60: structure, function and pathophysiology. J Physiol. 2012; 590(Pt 11): 2577-2589.

PubMled Abstract | Publisher Full Text | Free Full Text

20. Termin A, Martinborough E, Wilson D: Chapter 3 - Recent Advances in VoltageGated Sodium Channel Blockers: Therapeutic Potential as Drug Targets in the CNS. Annu Rep Med Chem. 2008; 43: 43-60. Publisher Full Text

21. Brackenbury WJ: Voltage-gated sodium channels and metastatic disease. Channels (Austin). 2012; 6(5): 352-361. PubMed Abstract | Publisher Full Text | Free Full Text

22. Lee $\mathrm{CH}$, Ruben PC: Interaction between voltage-gated sodium channels and the neurotoxin, tetrodotoxin. Channels (Austin). 2008; 2(6): 407-412. PubMed Abstract | Publisher Full Text

23. Fraser SP, Diss JK, Chioni AM, et al:: Voltage-gated sodium channel expression and potentiation of human breast cancer metastasis. Clin Cancer Res. 2005; 11(15): 5381-9.

PubMed Abstract | Publisher Full Text

24. Roger S, Rollin J, Barascu A: Voltage-gated sodium channels potentiate the invasive capacities of human non-small-cell lung cancer cell lines. Int $J$ Biochem Cell Biol. 2007; 39(4): 774-786. PubMed Abstract | Publisher Full Text

25. Blandino JK, Viglione MP, Bradley WA, et al.: Voltage-dependent sodium channels in human small-cell lung cancer cells: role in action potentials and inhibition by Lambert-Eaton syndrome IgG. J Membr Biol. 1995; 143(2): 153-163. inhibition by Lambert-Eaton syndrome
PubMed Abstract | Publisher Full Text

26. Diaz D, Delgadillo DM, Hernández-Gallegos E, et al:: Functional expression of voltage-gated sodium channels in primary cultures of human cervical cancer. 
J Cell Physiol. 2007; 210(2): 469-478.

PubMed Abstract | Publisher Full Text

27. Bennett ES, Smith BA, Harper JM: Voltage-gated $\mathrm{Na}^{+}$channels confer invasive properties on human prostate cancer cells. Pflugers Arch. 2004; 447(6): 908-914.

PubMed Abstract | Publisher Full Text

28. Gao R, Shen $\mathrm{Y}$, Cai J, et al:: Expression of voltage-gated sodium channel alpha subunit in human ovarian cancer. Oncol Rep. 2010; 23(5): 1293-1299. PubMed Abstract | Publisher Full Text

29. House CD, Vaske CJ, Schwartz AM, et al.: Voltage-gated $\mathrm{Na}^{+}$channel SCN5A is a key regulator of a gene transcriptional network that controls colon cancer invasion. Cancer Res. 2010; 70(17): 6957-67.

PubMed Abstract | Publisher Full Text | Free Full Text

30. Fraser SP, Diss JK, Lloyd LJ, et al:: T-lymphocyte invasiveness: control by voltage-gated $\mathrm{Na}^{+}$channel activity. FEBS Lett. 2004; 569(1-3): 191-194. PubMed Abstract | Publisher Full Text

31. Sato K, Ishizuka J, Cooper CW, et al:: Inhibitory effect of calcium channel blockers on growth of pancreatic cancer cells. Pancreas. 1994; 9(2): 193-202. PubMed Abstract | Publisher Full Text

32. Fulgenzi G, Graciotti L, Faronato M, et al.: Human neoplastic mesothelial cells express voltage-gated sodium channels involved in cell motility. Int J Biochem Cell Biol. 2006; 38(7): 1146-1159.

PubMed Abstract | Publisher Full Text

33. Grimes JA, Fraser SP, Stephens GJ, et al:: Differential expression of voltageactivated $\mathrm{Na}^{+}$currents in two prostatic tumour cell lines: contribution to invasiveness in vitro. FEBS Lett. 1995; 369(2-3): 290-294. PubMed Abstract | Publisher Full Text

34. Laniado ME, Lalani EN, Fraser SP: Expression and functional analysis of Voltage-activated $\mathrm{Na}^{+}$channels in human prostate cancer cell lines and their contribution to invasion in vitro. Am J Pathol. 1997; 150(4): 1213-1221. PubMed Abstract | Free Full Text

35. Smith $\mathrm{P}$, Rhodes NP, Shortland AP, et al:: Sodium channel protein expression enhances the invasiveness of rat and human prostate cancer cells. FEBS Lett. 1998; 423(1): 19-24.

PubMed Abstract | Publisher Full Text

36. Fraser SP, Salvador V, Manning EA, et al.: Contribution of functional voltagegated $\mathrm{Na}^{+}$channel expression to cell behaviors involved in the metastatic cascade in rat prostate cancer: I. Lateral motility. J Cell Physiol. 2003; 195(3): 479-87.

PubMed Abstract | Publisher Full Text

37. Roger S, Besson P, Le Guennec JY: Involvement of a novel fast inward sodium current in the invasion capacity of a breast cancer cell line. Biochim Biophys Acta. 2003; 1616(2): 107-111.

PubMed Abstract | Publisher Full Text

38. Batcioglu $\mathrm{K}$, Uyumlu $\mathrm{AB}$, Satilmis $\mathrm{B}$, et al: Oxidative stress in the in vivo DMBA rat model of breast cancer: suppression by a voltage-gated sodium channel inhibitor (RS100642). Basic Clin Pharmacol Toxicol. 2012; 111(2): 137-41. PubMed Abstract | Publisher Full Text

39. Brisson L, Driffort $\mathrm{V}$, Benoist $\mathrm{L}$, et al.: $\mathrm{Na}_{\mathrm{1}} \mathbf{1 . 5} \mathrm{Na}^{+}$channels allosterically regulate the NHE-1 exchanger and promote the activity of breast cancer cel invadopodia. J Cell Sci. 2013; 126(Pt 21): 4835-4842. PubMed Abstract | Publisher Full Text

40. Gillet L, Roger S, Besson P, et al.: Voltage-gated Sodium Channel Activity Promotes Cysteine Cathepsin-dependent Invasiveness and Colony Growth of Human Cancer Cells. J Biol Chem. 2009; 284(13): 8680-8691. PubMed Abstract | Publisher Full Text | Free Full Text

41. Mader CC, Oser M, Magalhaes MA, et al:: An EGFR-Src-Arg-Cortactin pathway mediates functional maturation of invadopodia and breast cancer cell invasion. Cancer Res. 2011; 71(5): 1730-1741.

PubMed Abstract | Publisher Full Text | Free Full Text

42. Clark ES, Whigham AS, Yarbrough WG, et al:: Cortactin is an essential regulator of matrix metalloproteinase secretion and extracellular matrix degradation in invadopodia. Cancer Res. 2007; 67(9): 4227-35.

PubMed Abstract | Publisher Full Text

43. Murphy DA, Courtneidge MA: The 'ins' and 'outs' of podosomes and invadopodia: characteristics, formation and function. Nat Rev Mol Cell Biol. 2011; 12(7): 413-426.

PubMed Abstract | Publisher Full Text | Free Full Text

44. Cosen-Binker LI, Kapus A: Cortactin: the gray eminence of the cytoskeleton. Physiology (Bethesda). 2006; 21: 352-361.

PubMed Abstract | Publisher Full Text

45. Onganer PU, Djamgoz MB: Small-cell lung cancer (human): potentiation of endocytic membrane activity by voltage-gated $\mathrm{Na}^{+}$channel expression in vitro. $J$ Membr Biol. 2005; 204(2): 67-75.

PubMed Abstract | Publisher Full Text

46. Tarone G, Cirillo D, Giancotti FG, et al.: Rous sarcoma virus-transformed fibroblasts adhere primarily at discrete protrusions of the ventral membrane called podosomes. Exp Cell Res. 1985; 159(1): 141-57.

PubMed Abstract | Publisher Full Text

47. Berdeaux RL, Diaz B, Kim L, et al:: Active Rho is localized to podosomes induced by oncogenic Src and is required for their assembly and function. J Cell Biol. 2004; 166(3): 317-323.

PubMed Abstract | Publisher Full Text | Free Full Text
48. Dulong C, Fang YJ, Gest C, et al.: The small GTPase RhoA regulates the expression and function of the sodium channel Nav1.5 in breast cancer cells. Int J Oncol. 2014; 44(2): 539-547.

PubMed Abstract | Publisher Full Text

49. Timpson P, McGhee EJ, Morton JP, et al:: Spatial regulation of RhoA activity during pancreatic cancer cell invasion driven by mutant p53. Cancer Res. 2011 71(3): 747-757.

PubMed Abstract | Publisher Full Text | Free Full Text

50. Andrikopoulos $\mathrm{P}$, Fraser SP, Patterson L, et al:: Angiogenic functions of voltagegated $\mathrm{Na}^{+}$Channels in human endothelial cells: modulation of vascula endothelial growth factor (VEGF) signaling. J Biol Chem. 2011; 286(19): 16846-16860.

PubMed Abstract | Publisher Full Text | Free Full Text

51. Litan A, Langhans SA: Cancer as a channelopaty: ion channels and pumps in tumor development and progression. Front Cell Neurosci. 2015; 9: 86 PubMed Abstract | Publisher Full Text | Free Full Text

52. Denac $\mathrm{H}$, Mevissen M, Scholtysik G, et al:: Structure, function and pharmacology of voltage-gated sodium channels. Naunyn Schmiedebergs Arch Pharmacol. 2000; 362(6): 453-479.

PubMed Abstract

53. Matsuki N, Quandt FN, Ten Eick RE, et al: Characterization of the block of sodium channels by phenytoin in mouse neuroblastoma cells. $J$ Pharmacol Exp Ther. 1984; 228(2): 523-30.

PubMed Abstract

54. Willow M, Gonoi T, Catterall WA, et al:: Voltage clamp analysis of the inhibitory actions of diphenylhydantoin and carbamazepine on voltage-sensitive sodium channels in neuroblastoma cells. Mol Pharmacol. 1985; 27(5): 549-58. PubMed Abstract

55. Schwinghammer TL, Howrie DL: Phenytoin-induced lymphadenopathy. Drug Intell Clin Pharm. 1983; 17(6): 460-2.

PubMed Abstract

56. Olsen JH, Boyce JD Jr, Jenssen JP, et al.: Cancer among epileptic patients exposed to anticonvulsant drugs. J Natl Cancer Inst. 1989; 81(10): 803-8. PubMed Abstract | Publisher Full Text

57. Okamoto $\mathrm{Y}$, Shimizu K, Tamura K, et al:: Effects of phenytoin on cell-mediated immunity. Cancer Immunol Immunother. 1988; 26(2): 176-9. PubMed Abstract | Publisher Full Text

58. Vernillo AT, Ramamurthy NS, Lee HM, et al: The effect of phenytoin on collagenase and gelatinase activities in UMR 106-01 rat osteoblastic osteosarcoma cells. Matrix. 1990; 10(1): 27-32. PubMed Abstract | Publisher Full Text

59. Dyce M, Sharif SF, Whalen GF, et al.: Search for anti-metastatic therapy: effects of phenytoin on B16 melanoma metastasis. J Surg Oncol. 1992; 49(2): 107-12. PubMed Abstract | Publisher Full Text

60. Yang M, Kozminski DJ, Wold LA, et al:: Therapeutic potential for phenytoin: targeting $\mathrm{Na}_{v} 1.5$ sodium channels to reduce migration and invasion in metastatic breast cancer. Breast Cancer Res Treat. 2012; 134(2): 603-615. PubMed Abstract | Publisher Full Text | Free Full Text

61. Ragsdale DS, Scheuer T, Catterall WA, et al.: Frequency and voltage dependent inhibition of type IIA Na+ channels, expressed in a mammalian cell line by loca anesthetic, antiarrhytmic and anticonvulsivant drugs. Mol Pharmacol. 1991; 40(5): 756-765. PubMed Abstract

62. Abdul M, Hoosein N: Inhibition by anticonvulsants of prostate-specific antigen and interleukin- 6 secretion by human prostate cancer cells. Anticancer Res. 2001; 21(3B): 2045-8. PubMed Abstract

63. Fadiel A, Song J, Tivon D, et al.: Phenytoin is an estrogen receptor $\alpha$-selective modulator that interacts with helix 12. Reprod Sci. 2015; 22(2): 146-55. PubMed Abstract | Publisher Full Text

64. Nelson M, Yang M, Dowle AA, et al.: The sodium channel-blocking antiepileptic drug phenytoin inhibits breast tumour growth and metastasis. Mol Cancer. 2015; 14(1): 13. PubMed Abstract | Publisher Full Text | Free Full Text

65. Lee TS, Chen LC, Liu Y, et al:: 5,5-Diphenyl-2-thiohydantoin-N10 (DPTH-N10) suppresses proliferation of cultured colon cancer cell line COLO-205 by inhibiting DNA synthesis and activating apoptosis. Naunyn Schmiedebergs Arch Pharmacol. 2010; 382(1): 43-50. PubMed Abstract | Publisher Full Text

66. Liu Y, Wu J, Ho PY, et al:: Anti-angiogenic action of 5,5-diphenyl-2thiohydantoin-N10 (DPTH-N10). Cancer Lett. 2008; 271(2): 294-305. PubMed Abstract | Publisher Full Text

67. Sikes RA, Walls AM, Brennen WN, et al:: Therapeutic approaches targeting prostate cancer progression using novel voltage-gated ion channel blockers. Clin Prostate Cancer. 2003; 2(3): 181-187. PubMed Abstract | Publisher Full Text

68. Anderson JD, Hansen TP, Lenkowski PW, et al:: Voltage-gated sodium channel blockers as cytostatic inhibitors of the androgen-independent prostate cancer cell line PC-3. Mol Cancer Ther. 2003; 2(11): 1149-54. PubMed Abstract

69. Lobert S, Ingram JW, Correia JJ, et al:: Additivity of dilantin and vinblastine inhibitory effects on microtubule assembly. Cancer Res. 1999; 59(19): 4816-22. PubMed Abstract 
70. Kawamura KI, Grabowski D, Weizer K, et al:: Modulation of vinblastine cytotoxicity by dilantin (phenytoin) or the protein phosphatase inhibitor okadaic acid involves the potentiation of anti-mitotic effects and induction of apoptosis in human tumour cells. Br J Cancer. 1996; 73(2): 183-8. PubMed Abstract | Publisher Full Text | Free Full Text

71. Lang DG, Wang CM, Cooper BR: Lamotrigine, phenytoin and carbamazepine interactions on the sodium current present in N4TG1 mouse neuroblastoma cells. J Pharmacol Exp Ther. 1993; 266(2): 829-35. PubMed Abstract

72. Tittle TV, Schaumann BA, Rainey JE, et al.: Segregation of the growth slowing effects of valproic acid from phenytoin and carbamazepine on lymphoid tumor cells. Life Sci. 1992; 50(14): PL79-83. PubMed Abstract | Publisher Full Text

73. Dosch HM, Jason J, Gelfand EW: Transient antibody deficiency and abnormal t-suppressor cells induced by phenytoin. N Engl J Med. 1982; 306(7): 406-409. PubMed Abstract | Publisher Full Text

74. Sorrell TC, Forbes IJ: Depression of immune competence by phenytoin and carbamazepine. Studies in vivo and in vitro. Clin Exp Immunol. 1975; 20(2): 273-85.

PubMed Abstract | Free Full Text

75. Fontana A, Grob PJ, Sauter R, et al.: IgA deficiency, epilepsy, and hydantoin medication. Lancet. 1976; 2(7979): 228-31.

PubMed Abstract | Publisher Full Text

76. Marcoli M, Gatti G, Ippoliti G, et al.: Effect of chronic anticonvulsant monotherapy on lymphocyte subpopulations in adult epileptic patients. Hum Toxicol. 1985; 4(2): 147-157.

PubMed Abstract

77. Teichmann M, Kretschy N, Kopf S, et al:: Inhibition of tumour spheroid-induced prometastatic intravasation gates in the lymph endothelial cell barrier by carbamazepine: drug testing in a 3D model. Arch Toxicol. 2014; 88(3): 691-9. PubMed Abstract | Publisher Full Text

78. Stettner M, Krämer G, Strauss A, et al.: Long-term antiepileptic treatment with histone deacetylase inhibitors may reduce the risk of prostate cancer. Eur Cancer Prev. 2012; 21(1): 55-64

PubMed Abstract | Publisher Full Text

79. Meng $\mathrm{Q}$, Chen $\mathrm{X}$, Sun L, et al.: Carbamazepine promotes Her-2 protein degradation in breast cancer cells by modulating HDAC6 activity and acetylation of Hsp90. Mol Cell Biochem. 2011; 348(1-2): 165-71. PubMed Abstract | Publisher Full Text

80. Meng QW, Zhao $\mathrm{CH}, \mathrm{Xi} \mathrm{YH}$, et al:: [Inhibitory effect of carbamazepine on proliferation of estrogen-dependent breast cancer cells]. Ai Zheng. 2006; 25(8): 967-73.

PubMed Abstract

81. Huang CW, Huang CC, Lin MW, et al.: The synergistic inhibitory actions of oxcarbazepine on voltage-gated sodium and potassium currents in differentiated NG108-15 neuronal cells and model neurons. Int $J$ Neuropsychopharmacol. 2008; 11(5): 597-610.

PubMed Abstract | Publisher Full Text

82. Beutler AS, Li SD, Nicol R, et al:: Carbamazepine is an inhibitor of histone deacetylases. Life Sci. 2005; 76(26): 3107-3115.

PubMed Abstract | Publisher Full Text

83. Kostrouchová M, Kostrouch Z, Kostrouchová M: Valproic acid, a molecular lead to multiple regulatory pathways. Folia Biol (Praha). 2007; 53(2): 37-49. PubMed Abstract

84. Michaelis M, Doerr HW, Cinatl J Jr: Valproic acid as anti-cancer drug. Curr Pharm Des. 2007; 13(33): 3378-93.

PubMed Abstract | Publisher Full Tex

85. Banon D, Filion KB, Budlovsky T, et al.: The usefulness of ranolazine for the treatment of refractory chronic stable angina pectoris as determined from a systematic review of randomized controlled trials. Am J Cardiol. 2014; 113(6): 1075-1082.

PubMed Abstract | Publisher Full Text

86. Driffort V, Gillet L, Bon E, et al:: Ranolazine inhibits Na 1.5-mediated breast cancer cell invasiveness and lung colonization. Mol Cancer. 2014; 13: 264 PubMed Abstract | Publisher Full Text

87. Djamgoz MB, Onkal R: Persistent current blockers of voltage-gated sodium channels: a clinical opportunity for controlling metastatic disease. Recent Pat Anticancer Drug Discov. 2013; 8(1): 66-84. PubMed Abstract | Publisher Full Text

88. Ingolfsson $\mathrm{HI}$, Thakur $\mathrm{P}$, Herold $\mathrm{KF}$, et al:: Phytochemicals perturb membranes and promiscuously alter protein function. ACS Chem Biol. 2014; 9(8): 1788-1798. PubMed Abstract | Publisher Full Text | Free Full Text

89. Fraser SP, Peters A, Fleming-Jones S, et al.: Resveratrol: inhibitory effects on metastatic cell behaviors and voltage-gated $\mathrm{Na}^{+}$channel activity in rat prostate cancer in vitro. Nutr Cancer. 2014; 66(6): 1047-58. PubMed Abstract | Publisher Full Text

90. Weixel KM, Marciszyn A, Alzamora R, et al:: Resveratrol inhibits the epithelial sodium channel via phopshoinositides and AMP-activated protein kinase in kidney collecting duct cells. Plos One. 2013; 8(19): e78019. PubMed Abstract | Publisher Full Text | Free Full Text

91. Wallace $\mathrm{CH}$, Baczkó $\mathrm{I}$, Jones $\mathrm{L}$, et al:: Inhibition of cardiac voltage-gated sodium channels by grape polyphenols. Br J Pharmacol. 2006; 149(6): 657-665. PubMed Abstract | Publisher Full Text | Free Full Text
92. Jia Z, Jia Y, Liu B, et al:: Genistein inhibits voltage-gated sodium currents in SCG neurons through protein tyrosine kinase-dependent and kinaseindependent mechanisms. Pflugers Arch. 2008; 456(5): 857-66.

PubMed Abstract | Publisher Full Text

93. Liu L, Yang $T$, Simon SA: The protein tyrosine kinase inhibitor, genistein, decreases excitability of nociceptive neurons. Pain. 2004; 112(1-2): 131-41. PubMed Abstract | Publisher Full Text

94. Zhang JL, Yang JP, Zhang JR, et al:: Gabapentin reduces allodynia and hyperalgesia in painful diabetic neuropathy rats by decreasing expression level of Nav1.7 and p-ERK1/2 in DRG neurons. Brain Res. 2013; 1493: 13-8. PubMed Abstract | Publisher Full Text

95. Yang RH, Wang WT, Chen JY, et al:: Gabapentin selectively reduces persisten sodium current in injured type-A dorsal root ganglion neurons. Pain. 2009; 143(1-2): 48-55.

PubMed Abstract | Publisher Full Text

96. Liu Y, Qin N, Reitz T, et al.: Inhibition of the rat brain sodium channel Nav1.2 after prolonged exposure to gabapentin. Epilepsy Res. 2006; 70(2-3): 263-8. PubMed Abstract | Publisher Full Text

97. Abdul $\mathrm{M}$, Hoosein $\mathrm{N}$ : Voltage-gated sodium ion channels in prostate cancer: expression and activity. Anticancer Res. 2002; 22(3): 1727-30. PubMed Abstract

98. Wall BA, Wangari-Talbot J, Shin SS, et al.: Disruption of GRM1-mediated signalling using riluzole results in DNA damage in melanoma cells. Pigment Cell Melanoma Res. 2014; 27(2): 263-74. PubMed Abstract | Publisher Full Text | Free Full Text

99. Kiskin NI, Chizhmakov IV, Tsyndrenko AYa, et al.: R56865 and flunarizine as $\mathbf{N a}^{+-}$ channel blockers in isolated Purkinje neurons of rat cerebellum. Neuroscience. 1993; 54(3): 575-85.

PubMed Abstract | Publisher Full Text

100. Fischer W, Kittner H, Regenthal R, et al:: Anticonvulsant profile of flunarizine and relation to $\mathrm{Na}^{+}$channel blocking effects. Basic Clin Pharmacol Toxicol. 2004; 94(2): 79-88.

PubMed Abstract | Publisher Full Text

101. Ye Q, Yan LY, Xue LJ, et al:: Flunarizine blocks voltage-gated $\mathbf{N a}^{+}$and $\mathrm{Ca}^{2+}$ currents in cultured rat cortical neurons: A possible locus of action in the prevention of migraine. Neurosci Lett. 2011; 487(3): 394-9.

PubMed Abstract | Publisher Full Text

102. Francis J, Burnham WM: [3H]Phenytoin identifies a novel anticonvulsantbinding domain on voltage-dependent sodium channels. Mol Pharmacol. 1992; 42(6): 1097-103. PubMed Abstract

103. Schmeel LC, Schmeel FC, Kim Y, et al.: Flunarizine exhibits in vitro efficacy against lymphoma and multiple myeloma cells. Anticancer Res. 2015; 35(3) 1369-76 PubMed Abstract

104. Conrad DM, Furlong SJ, Doucette CD, et al:: The $\mathrm{Ca}^{2+}$ channel blocker flunarizine induces caspase-10-dependent apoptosis in Jurkat T-leukemia cells. Apoptosis. 2010; 15(5): 597-607.

PubMed Abstract | Publisher Full Tex

105. Fink-Puches $\mathrm{R}$, Helige $\mathrm{C}$, Kerl $\mathrm{H}$, et al.: Inhibition of melanoma cell directional migration in vitro via different cellular targets. Exp Dermatol. 1993; 2(1): 17-24. PubMed Abstract | Publisher Full Text

106. Hofmann-Wellenhof R, Fink-Puches R, Smolle J, et al.: Correlation of melanoma cell motility and invasion in vitro. Melanoma Res. 1995; 5(5): 311-9. PubMed Abstract | Publisher Full Text

107. Sezzi ML, De Luca G, Materazzi M, et al:: Effects of a calcium-antagonist (flunarizine) on cancer cell movement and phagocytosis. Anticancer Res. 1985; 5(3): 265-71. PubMed Abstract

108. Kaelin WG Jr, Shrivastav S, Jirtle RL: Blood flow to primary tumors and lymph node metastases in SMT-2A tumor-bearing rats following intravenous flunarizine. Cancer Res. 1984; 44(3): 896-9. PubMed Abstract

109. Bellelli A, Camboni C, de Luca G, et al:: In vitro and in vivo enhancement of vincristine antitumor activity on B16 melanoma cells by calcium antagonist flunarizine. Oncology. 1987; 44(1): 17-23. PubMed Abstract | Publisher Full Text

110. Vaupel $\mathrm{P}$, Menke $\mathrm{H}$ : Blood flow, vascular resistance and oxygen availability in malignant tumours upon intravenous flunarizine. Adv Exp Med Biol. 1987; 215 393-8.

PubMed Abstract | Publisher Full Text

111. Wood PJ, Hirst DG: Cinnarizine and flunarizine as radiation sensitisers in two murine tumours. Br J Cancer. 1988; 58(6): 742-745. PubMed Abstract | Publisher Full Text | Free Full Tex

112. Astin JW, Jamieson SM, Eng TC, et al: An in vivo antilymphatic screen in zebrafish identifies novel inhibitors of mammalian lymphangiogenesis and lymphatic-mediated metastasis. Mol Cancer Ther. 2014; 13(10): 2450-62. PubMed Abstract | Publisher Full Text

113. Gornati D, Zaffaroni N, Villa R, et al.: Modulation of melphalan and cisplatin cytotoxicity in human ovarian cancer cells resistant to alkylating drugs. Anticancer Drugs. 1997; 8(5): 509-16.

PubMed Abstract | Publisher Full Text

114. Castellino SM, Friedman HS, Elion GB, et al.: Flunarizine enhancement of 
melphalan activity against drug-sensitive/resistant rhabdomyosarcoma. $\mathrm{Br} \mathrm{J}$ Cancer. 1995; 71(6): 1181-7.

PubMed Abstract | Publisher Full Text | Free Full Text

115. Silvestrini R, Zaffaroni N, Costa A, et al.: Flunarizine as a modulator of doxorubicin resistance in human colon-adenocarcinoma cells. Int $J$ Cancer. 1993; 55(4): 636-9.

PubMed Abstract | Publisher Full Text

116. Kavanagh BD, Coffey BE, Needham D, et al.: The effect of flunarizine on erythrocyte suspension viscosity under conditions of extreme hypoxia, low pH, and lactate treatment. Br J Cancer. 1993; 67(4): 734-741. PubMed Abstract | Publisher Full Text | Free Full Text

117. Sezzi ML, Zupi G, De Luca G, et al.: Effects of a calcium-antagonist (flunarizine) on the in vitro growth of B16 mouse melanoma cells. Anticancer Res. 1984; 4(4-5): 229-34. PubMed Abstract

118. So HS, Kim HJ, Lee JH, et al.: Flunarizine induces Nrf2-mediated transcriptional activation of heme oxygenase- 1 in protection of auditory cells from cisplatin. Cell Death Differ. 2006; 13(10): 1763-1755. PubMed Abstract | Publisher Full Text

119. Kang HJ, YI, Hong YB, et al:: HER2 confers drug resistance of human breast cancer cells through activation of NRF2 by direct interaction. Sci Rep. 2014; 4 7201.

PubMed Abstract | Publisher Full Text | Free Full Text

120. Sakaguchi $M$, Kuroda $Y$, Hirose $M$ : The antiproliferative effect of lidocaine on human tongue cancer cells with inhibition of the activity of epidermal growth factor receptor. Anesth Analg. 2006; 102(4): 1103-1107. PubMed Abstract | Publisher Full Text

121. Mammoto $\mathrm{T}$, Higashiyama S, Mukai M, et al.: Infiltration anesthetic lidocaine inhibits cancer cell invasion by modulating ectodomain shedding of heparinbinding epidermal growth factor-like growth factor (HB-EGF). J Cell Physiol. 2002; 192(3): 351-8.

PubMed Abstract | Publisher Full Text

122. Baptista-Hon DT, Robertson FM, Robertson GB, et al.: Potent inhibition by ropivacaine of metastatic colon cancer SW620 cell invasion and $\mathrm{Na}_{\mathrm{v}} 1.5$ channel function. Br J Anaesth. 2014; 113( Suppl 1): i39-i48. PubMed Abstract | Publisher Full Text

123. Piegeler T, Votta-Velis EG, Liu G, et al:: Antimetastatic potential of amidelinked local anesthetics: inhibition of lung adenocarcinoma cell migration and inflammatory Src signaling independent of sodium channel blockade. Anesthesiology. 2012; 117(3): 548-559.

PubMed Abstract | Publisher Full Text | Free Full Text

124. Poulin $\mathrm{H}$, Bruhova I, Timour $\mathrm{Q}$, et al.: Fluoxetine blocks $\mathrm{Na}_{v} 1.5$ channels via a mechanism similar to that of class 1 antiarrhythmics. Mol Pharmacol. 2014; 86(4): 378-89.

PubMed Abstract | Publisher Full Text | Free Full Text

125. Wang Y, Mi J, Lu K, et al.: Comparison of Gating Properties and Use-Dependent Block of $\mathrm{Na}_{\mathrm{v}} \mathrm{1.5}$ and $\mathrm{Na}_{\mathrm{v}} 1.7$ Channels by Anti-Arrhythmics Mexiletine and Lidocaine. PLoS One. 2015; 10(6): e0128653.

PubMed Abstract | Publisher Full Text | Free Full Text

126. Mammoto T, Mukai M, Mammoto A, et al:: Intravenous anesthetic, propofol inhibits invasion of cancer cells. Cancer Lett. 2002; 184(2): 165-70. PubMed Abstract | Publisher Full Text

127. Besson $\mathrm{P}$, Driffort $\mathrm{V}$, Bon É, et al.: How do voltage-gated sodium channels enhance migration and invasiveness in cancer cells? Biochim Biophys Acta. 2015; pii: S0005-2736(15)00136-4 PubMed Abstract | Publisher Full Text

128. Brown MT, Herrmann DN, Goldstein M, et al:: Nerve safety of tanezumab, a nerve growth factor inhibitor for pain treatment. J Neurol Sci. 2014; 345(1-2): 139-47. PubMed Abstract | Publisher Full Text

129. Kalman D, Wong B, Horvai AE, et al:: Nerve growth factor acts through cAMPdependent protein kinase to increase the number of sodium channels in PC12 cells. Neuron. 1990; 4(3): 355-366. PubMed Abstract | Publisher Full Text

130. Mnich K, Carleton LA, Kavanagh ET, et al:: Nerve growth factor-mediated inhibition of apoptosis post-caspase activation is due to removal of active caspase-3 in a lysosome-dependent manner. Cell Death Dis. 2014; 5: e1202. PubMed Abstract | Publisher Full Text | Free Full Text

131. Chioni AM, Brackenbury WJ, Calhoun JD, et al:: A novel adhesion molecule in human breast cancer cells: voltage-gated $\mathrm{Na}^{+}$channel beta1 subunit. Int $\mathrm{J}$ Biochem Cell Biol. 2009; 41(5): 1216-1227. PubMed Abstract | Publisher Full Text | Free Full Text

132. Nelson M, Millican-Slater R, Forrest LC, et al:: The sodium channel $\beta 1$ subunit mediates outgrowth of neurite-like processes on breast cancer cells and promotes tumour growth and metastasis. Int J Cancer. 2014; 135(10): 2338-2351.

PubMed Abstract | Publisher Full Text | Free Full Text

133. Brisson $\mathrm{L}$, Gillet $\mathrm{L}$, Calaghan $\mathrm{S}$, et al:: $\mathrm{Na}_{\mathrm{v}} \mathbf{1 . 5}$ enhances breast cancer cell invasiveness by increasing NHE1-dependent $\mathrm{H}^{+}$efflux in caveolae. Oncogene. 2011; 30(17): 2070-2076. PubMed Abstract | Publisher Full Text

134. Stettner M, Krämer G, Strauss A, et al:: Long-term antiepileptic treatment with histone deacetylase inhibitors may reduce the risk of prostate cancer. Eur $J$ Cancer Prev. 2012; 21(1): 55-64.

PubMed Abstract | Publisher Full Text 


\section{Open Peer Review}

\section{Current Peer Review Status:}

\section{Version 1}

Reviewer Report 22 June 2016

https://doi.org/10.5256/f1000research.7293.r14301

(C) 2016 Mutoh M. This is an open access peer review report distributed under the terms of the Creative Commons Attribution License, which permits unrestricted use, distribution, and reproduction in any medium, provided the original work is properly cited.

\section{Michihiro Mutoh}

Epidemiology and Prevention Division, Research Center for Cancer Prevention and Screening, National Cancer Center, Chuo-ku, Japan

This manuscript is well summarized with topics. However, I believe some more information needs to be added.

1. As small molecules, such as FDA approved drugs, affect the tissue of the whole body, the information of the data from genetic findings, such as NaV1.5 knockout mice data, is desired to be included in the text

2. The idea that selecting the voltage gated sodium channel blocker by repurposing of a drug seems attractive to fight invasion and metastasis of cancer. However, a concrete example for the medical use is not shown in the text. Please provide an idea when a patient could use such a drug.

3. Oxidative stress contributes to the invasion process. Figures $3 \& 4$ show that proton exfusion also plays a role in the invadopodia complex. Do the author has an idea to connect oxidative stress and the voltage gated sodium channel? If not, please ignore this comment.

4. Figure 7: "B1 subunit" should be replaced by "b(symbol)1 subunit".

5. The author describes in the text that the voltage gated sodium channel is overexpressed in cancer tissue, and its blockers could be used as cancer chemoprevention agents. It might be worth writing a review article regarding carcinogenesis and the voltage gated sodium channel blocker in the future.

Competing Interests: No competing interests were disclosed.

I confirm that I have read this submission and believe that I have an appropriate level of expertise to confirm that it is of an acceptable scientific standard. 
Reviewer Report 19 May 2016

https://doi.org/10.5256/f1000research.7293.r13165

(C) 2016 Waxman S. This is an open access peer review report distributed under the terms of the Creative Commons Attribution License, which permits unrestricted use, distribution, and reproduction in any medium, provided the original work is properly cited.

\section{Stephen G. Waxman}

Department of Neurology, Yale University, New Haven, CT, USA

This article focuses attention on sodium channels as potential therapeutic targets for metastatic disease. Much work needs to be done to determine whether agents that act on sodium channels will blunt metastatic activity in a clinically meaningful manner, but a spectrum of sodium channel blockers with only minimal side-effects are already used clinically. This novel approach thus merits careful study.

While at first glance it may seem surprising that voltage-gated sodium channels are proposed as molecular targets within (presumably) non-excitable cells, there are many precedents for a role of these channels in controlling effector actions in multiple types of cells that have traditionally been considered non-excitable ${ }^{1}$. One example is provided by astrocytes, which express multiple types of sodium channels that are functional within the cell membrane ${ }^{2}$. These astrocytic sodium channels provide a return pathway for $\mathrm{Na}$ ions that facilitates operation of the Na-K/ATPase in these cells ${ }^{3}$. Notably, expression of sodium channels within astrocytes is highly dynamic, a phenomenon that is strikingly seen in scarring astrocytes in disorders such as multiple sclerosis (MS) and its models where expression of Nav1.5 is up-regulated ${ }^{4}$. Recent evidence indicates that these glial sodium channels participate in the astrocytic response to injury, via a cascade that involves $\mathrm{Na}$ influx that activates reverse (Ca-importing) $\mathrm{Na} / \mathrm{Ca}$ exchange ${ }^{5}$. Given the large number of traditionally non-excitable cell-types (including microglia, macrophages, and multiple other celltypes) where expression of voltage-gated sodium channels and a functional role for these channels has been documented (reviewed in Black and Waxman, 2013 ${ }^{1}$ ), sodium channels may emerge as therapeutic targets in multiple disorders.

\section{References}

1. Black JA, Waxman SG: Noncanonical roles of voltage-gated sodium channels.Neuron. 2013; 80 (2): 280-91 PubMed Abstract | Publisher Full Text

2. Sontheimer H, Black JA, Ransom BR, Waxman SG: Ion channels in spinal cord astrocytes in vitro. I. Transient expression of high levels of $\mathrm{Na}+$ and K+ channels.J Neurophysiol. 1992; 68 (4): 985-1000 PubMed Abstract

3. Sontheimer $\mathrm{H}$, Fernandez-Marques E, Ullrich N, Pappas CA, et al.: Astrocyte $\mathrm{Na}+$ channels are required for maintenance of Na+/K(+)-ATPase activity.J Neurosci. 1994; 14 (5 Pt 1): 2464-75 PubMed Abstract

4. Black JA, Newcombe J, Waxman SG: Astrocytes within multiple sclerosis lesions upregulate sodium channel Nav1.5.Brain. 2010; 133 (Pt 3): 835-46 PubMed Abstract | Publisher Full Text 5. Pappalardo LW, Samad OA, Black JA, Waxman SG: Voltage-gated sodium channel Nav 1.5 contributes to astrogliosis in an in vitro model of glial injury via reverse $\mathrm{Na}+/ \mathrm{Ca} 2+$ exchange.Glia. 2014; 62 (7): 1162-75 PubMed Abstract | Publisher Full Text 
Competing Interests: No competing interests were disclosed.

I confirm that I have read this submission and believe that I have an appropriate level of expertise to confirm that it is of an acceptable scientific standard.

The benefits of publishing with F1000Research:

- Your article is published within days, with no editorial bias

- You can publish traditional articles, null/negative results, case reports, data notes and more

- The peer review process is transparent and collaborative

- Your article is indexed in PubMed after passing peer review

- Dedicated customer support at every stage

For pre-submission enquiries, contact research@f1000.com 